Mirosława Czetyrba-Piszczako

Olsztyn

Maria Czetyrba

Poznań

\title{
Tożsamość kulturowa i identyfikacja językowa Ukraińców Warmii i Mazur
}

Słowa kluczowe: mniejszość ukraińska, tożsamość kulturowa i językowa, asymilacja, bilingwizm językowy

Po II wojnie światowej w wyniku przyłączenia do Polski obszarów zwanych Warmią i Mazurami, Prusami Wschodnimi lub Pomorzem Wschodnim całkowitej deformacji uległa struktura narodowościowa tego regionu. Obok historycznie zasiedziałej ludności Warmiaków i Mazurów miejsce wysiedlonych Niemców zapełnili osadnicy z Centralnej Polski, repatrianci z dawnych Kresów Wschodnich oraz przymusowo przesiedlona w 1947 r. ludność ukraińska, która stanowiła wówczas około $10 \%$ ogółu ludności regionu [Beba, Pijanowska 1998, 24]. Masowy proces wymiany ludności przyczynił się do zintegrowania na obszarze jednego regionu przedstawicieli różnych grup narodowych i etnicznych, jak również zetknięcia się społeczeństw o różnym bagażu kulturowym, cywilizacyjnym i zróżnicowanej świadomości narodowej. W rezultacie migracji i wyniku ,zetknięcia się odrębności etnicznych i kulturowych powstało pogranicze społeczności złożonej z ludności rodzimej z ukształtowaną od pokoleń tożsamością oraz społeczności postmigracyjnej, w której przez dziesięciolecia dokonuje się proces tworzenia nowej tożsamości regionalnej” [Protokół Nr 20/2009, online]. Wśród naukowców i badaczy nie ma obecnie klarownego stanowiska odnośnie kwestii istnienia tożsamości regionalnej na tzw. Ziemiach Odzyskanych. O tożsamości Warmii i Mazu- 
rach Andrzej Sakson pisze, że „[...] o ile da się wyodrębnić na tych terenach odpowiednik tożsamości lokalnej, o tyle ciężko wskazać wyznaczniki tożsamości regionalnej. I to mimo wskazanego w badaniach empirycznych faktu autoidentyfikacji z miejscem życia i regionem" [Chmielewski 2013, 356].

Współcześnie region Warmii i Mazur, obok Podlasia, jawi się jako swoisty tygiel wielokulturowy charakteryzujący się dużą różnorodnością narodową, etniczną, religijną i językową, gdzie mniejszości stanowią około $10 \%$ populacji. Na Warmii i Mazurach najliczniejszą grupą mniejszościową są Ukraińcy zamieszkujący północną część województwa od Braniewa po Banie Mazurskie. Duża koncentracja społeczności ukraińskiej występuje w Olsztynie, Mrągowie, Górowie Iławeckim, Bartoszycach, Węgorzewie. Z raportu badań przeprowadzonych przez Instytut Spraw Publicznych wynika, że „ponad pięćdziesięcioletnie zamieszkanie $\mathrm{w}$ środowisku wielokulturowym i wieloetnicznym spowodowało znacznie większą niż w innych regionach kraju tolerancję w stosunku do inności, [...] a ten region wyróżnia się wyjątkowo przychylną postawą zarówno wobec imigrantów z Ukrainy, czy ogólnie obywateli tego kraju, jak też wobec samej mniejszości ukraińskiej" [Konieczna, online].

Niniejszy artykuł traktuje o kształtowaniu się w świadomości przesiedlonych Ukraińców nowej tożsamości społeczno-kulturowej poprzez podtrzymywanie poczucia odrębności językowo-religijnej oraz identyfikacji narodowej po długotrwałym jej funkcjonowaniu w obcym środowisku językowym, niesprzyjającej atmosferze życia kulturalnego, religijnego i politycznego. Zawarte w artykule rozważania i wnioski sformułowane zostały także w oparciu o analizę wywiadów przeprowadzonych wśród zróżnicowanej wiekowo grupy Ukraińców w 2013 roku, podejmujących kwestie kultywowania i nazewnictwa wybranych elementów tradycji oraz obrzędów świąt rocznych i rodzinnych.

Beba B. na podstawie przeprowadzonych w latach 90. badań ankietowych reasumuje, że tożsamość kulturowa Ukraińców „ewoluowała od postaci kultury niejako danej, mającej charakter introwertyczny, w której podmioty, czyli osoby w niej żyjące, w większości nie reflektowały nad jej treściami i formami, ani też nad własnymi postawami - w kierunku tożsamości, opierającej się na bardzo zróżnicowanej - w sensie typu istnienia i genezy różnych nurtów - kulturze. Ta zróżnicowana kultura ma w sobie wątki zarówno kultury ludowej, jak i elitarnej, narodowej - tradycyjnej i współczesnej, wobec której występują postawy dystansu i refleksji" [Beba 1998, 107]. Przez dziesięciolecia po przesiedleniu czynniki kształtujące poczucie identyfikacji ze zbiorowością ukraińską opierały się na trzech podstawowych instytucjach, a mianowicie rodzinie, cerkwi i szkole. Każdy z tych filarów w warunkach asymilacji 
realizował określone zadania przekazu kulturowego. Zdaniem T. Marciniaka „jesteśmy świadkami transformacji formy obecności ukraińskiej od czysto symbolicznej, w postaci np. rękodzieła krzyżykowego kultywowanego w zaciszu domowym, do fizycznej, zewnętrznej poprzez promowanie dziedzictwa kulturowego w społeczności polskiej" [Marciniak 1998, 118-127].

Wysiedlenie ludności ukraińskiej z terenów południowo-wschodniej Polski, które od stuleci zamieszkiwali, spowodowało nieodwracalne skutki nagłego zrujnowania kultury duchowej przesiedleńców, wskutek pozbawienia Ukraińców nauki języka ojczystego i możliwości celebrowania nabożeństw we własnym obrządku. Dodatkowo, zaostrzone dyrektywy osiedlania w rozproszeniu miały na celu szybkie wynarodowienie przesiedlonej ludności. Pozbawieni swojej „małej ojczyzny” Ukraińcy traktowali pobyt na „ziemiach odzyskanych" jako sytuację tymczasową i jak podkreśla I. Hrywna, „rzuceni w nowe polskie środowisko Ukraińcy żyli myślą o rychłym powrocie na stare ziemie, dlatego do końca lat czterdziestych większość $\mathrm{z}$ nich, nie przejawiała zainteresowania zagospodarowaniem się $\mathrm{w}$ województwie olsztyńskim. Otoczeni niechęcią polskich sąsiadów zamknęli się w swoim getcie" [Hrywna 1998, 109]. Pierwsze powojenne dziesięciolecie pokazuje, że specyficzną cechą przesiedleńców ukraińskich był raczej zamknięty lub ograniczający się jedynie do kontaktów sąsiedzkich tryb życia, który kształtował oblicze językowo-etniczne grypy oraz chronił ją przed wpływami otoczenia polskiego z jego oddziaływaniem asymilacyjnym. Głęboko zakorzeniona w umysłach przesiedleńców samoświadomość etniczna stała się naturalną drogą do kształtowania się świadomości narodowej oraz identyfikowania się z narodem ukraińskim. Przymusowa migracja oraz zagrożenie procesami asymilacyjnymi było przyczyną zacierania się różnorodności kulturowo-językowej przesiedlonych ukraińskich grup etnicznych i kształtowania się tożsamości narodowej w wyniku odstąpienia poszczególnych zbiorowości od tożsamości etnicznej na rzecz samouświadomienia jako narodu ukraińskiego. Silnie pielęgnowane poczucie tożsamości etnicznej chroniło mniejszość ukraińską przed zepchnięciem jej na margines życia w nowym środowisku oraz zabezpieczało przed bezkrytycznym przyjmowaniem elementów nowej, obcej kultury „czyniąc ją psychologicznie i społecznie silną w relacji do nowej kultury i społeczności" [Skorowski 2013, 20]. Z drugiej strony fizyczne oderwanie Ukraińców od własnego regionalnego środowiska oraz ugruntowanie się ogólnej tożsamości narodowej, które odbywało się kosztem utraty specyficznych cech i elementów samoświadomości etnicznej, np. utraty swojej gwary i zwyczajów na rzecz wartości ogólnonarodowych, zaowocowało małżeństwami etnicznie mieszanymi. Jak twierdzą respondenci, w kontekście pojawienia się odrębności kulturowych 
i językowych wykształciła się u nich nowa świadomość pojmowania określeń „swój”, „obcy”. W obcym kulturowo środowisku zdezaktualizowała się interpretacja, że swój to ten, kto przynależy do tej samej zbiorowości etnicznej. W nowym otoczeniu semantyka terminu „swój” zawierała się w ogólnym pojęciu „Ukrainiec”, a nie, jak pojmowano to wcześniej, nazywała jedynie przedstawiciela określonej grupy etnicznej, jak np. Łemko, Bojko, ,jarosławski”.

Na obszarze Warmii i Mazur, wskutek przekroczenia limitów osadniczych, pojawiły się miejscowości praktycznie w całości zamieszkałe przez ludność ukraińską (np. wsie Asuny, Augamy, Jarzeń, Wróble), co w późniejszym okresie miało ogromne znaczenie dla identyfikowania się z tą etniczną grupa społeczną i kultywowania mowy rodzimej, która znalazła swoją ostoję w życiu rodzinno-sąsiedzkim. Tak, na przykład, Banie Mazurskie ze względu na zintegrowanie społeczności ukraińskiej i szeroko zakrojoną działalność społeczno-kulturalną zyskały w latach 70-80. miano „stolicy mazurskiej Ukrainy".

Dla przesiedlonej społeczności ukraińskiej następstwem migracji o charakterze przymusowym była degradacja poziomu kulturowo-społecznego, a prowadzona w stosunku do Ukraińców polityka wynarodowienia nie sprzyjała adaptacji w nowej i obcej rzeczywistości. W konsekwencji zabiegi ówczesnych władz podejmowane w celu wykorzenienia poczucia przynależności narodowej przesiedleńców przyczyniły się do potrzymania i umocnienia się tożsamości kulturowej Ukraińców. Proces przechodzenia jednostki w świat innej kultury i społeczności H. Skorowski charakteryzuje następująco: „sytuację osoby przechodzącej w nową rzeczywistość społeczno-kulturową wyznaczają dwa elementy - element fizycznego oderwania od własnych struktur społeczno-kulturowych, a także element zderzenia z nowymi tego rodzaju strukturami. Sytuacja ta pociągać może za sobą różnorakie skutki społeczno-moralne: od zsunięcia się człowieka na margines życia społecznego [...] poprzez zagubienie jako wynik deprecjacji wartości i norm starego systemu społecznego i niezastąpienia ich nowymi; aż po pełną inkorporację w nową rzeczywistość [...]" [Skorowski 2013, 19].

Obserwujemy, że wielokierunkowe procesy przepływów i wzajemnych oddziaływań są konsekwencją zasymilowania w kulturze społeczności ukraińskiej elementów kultury polskiej, np. wielu respondentów podkreśla obecność karpia w galarecie na ich stołach wigilijnych.

W warunkach wielokulturowości podstawą procesów integracyjnych społeczności ukraińskiej, obok, poczucia solidarności, etnocentryzmu jest homogeniczna tożsamość kulturowa stanowiąca umacniającą świadomość wspólnych losów w przeszłości oraz kształtowanie się świadomości narodo- 
wej. W województwie warmińsko-mazurskim Ukraińcy żyją w dużym rozproszeniu, są zinstytucjonalizowani praktycznie w jednej organizacji nadrzędnej, którą jest Związek Ukraińców w Polsce, ale „z racji większej liczebności i większego stopnia skupienia charakter życia etnicznego został w środowiskach ukraińskich w większym stopniu zachowany" [Domagała 2005, 87]. Jak słusznie zauważa Marciniak, „w obecnej sytuacji szybkiego przepływu wzorców kulturowych niemożliwe jest podtrzymanie tożsamości etnicznej bez etnozasilania zewnętrznego czyli jednostronnego przepływu wartości kulturowych i ekonomicznych z kraju macierzystego lub z posiadającej pod tym względem większy potencjał innej grupy diaspory etnicznej/narodowej" [Marciniak 1998, 125]. Według badacza ciągłość przekazu kulturowego i pobudzanie świadomości narodowej wspierane jest przez środki zewnętrzne i wewnętrzne, które określa mianem entozasilania zewnętrznego i wewnętrznego. Obecnie, co podkreśla Marciniak, Ukraińcy muszą wytworzyć własne metody utrzymania samoidentyfikacji, aby trwać i rozwijać się i są to formy etnozasilania wewnętrznego, natomiast wcześniej mogli posiłkować się wsparciem diaspory przede wszystkim kanadyjskiej w okresie głębokiego komunizmu i przemian polityczno-społecznych lat 80. oraz Ukrainy po odzyskaniu niepodległości w $1991 \mathrm{r}$. Polityka narodowa PRL-u nie wykazywała się tolerancyjnością i nie stwarzała warunków sprzyjających pielęgnowaniu tradycji kulturowych mniejszości. Dopiero od początku lat 90. rozkwitła działalność kulturowa między ośrodkami skupiającymi najliczniejszą mniejszość ukraińską a poszczególnymi miastami partnerskimi na Ukrainie, która zaowocowała podpisaniem umów partnerskich wspierających tożsamość kulturową, działalność ruchu artystycznego, edukację młodzieży, które miały istotne znaczenie dla ekspansji oraz dynamizacji kultury mniejszości ukraińskiej.

Raport z wyników Narodowego Spisu Powszechnego z 2011 r. podaje, że w województwie warmińsko-mazurskim odnotowano w sumie 13 tys. (w Polsce 49 tys.) deklaracji, w których ankietowani podali narodowość ukraińską, z czego 9 tys. (w Polsce 27 tys.) wyraziło ją jako identyfikację pojedynczą, zaś 4 tys. łącznie z polską.

Powszechny Spis Narodowy z 2011 r., po raz pierwszy w historii polskich spisów ludności, umożliwił mieszkańcom Polski, na wniosek środowisk mniejszościowych, wyrażenie złożonych tożsamości narodowo-etnicznych poprzez zadanie osobom spisywanym dwóch pytań o przynależność narodowo-etniczną w brzmieniu: jaka jest Pan(-i) narodowość; czy odczuwa Pan(-i) przynależność także do innego narodu lub wspólnoty etnicznej. Przypomnijmy, że podczas spisu 2002 respondenci mogli zadeklarować tylko jedną przynależność narodowo-etniczną. 
Mobilizacja społeczności ukraińskiej oraz zakrojona na szeroką skalę kampania informacyjna w postaci wzmianek o spisie w telewizji i Internecie czy publiczna deklaracja tożsamości liderów środowisk ukraińskich zachęcająca do zgłaszania swojej narodowości, nie dała satysfakcjonujących rezultatów, bo w porównaniu z wynikami Spisu Powszechnego z 2002 r. liczebność mniejszości ukraińskiej zwiększyła się tylko o 11.623 osoby. Dodatkowo pojawiły się wątpliwości co do obiektywności spisu w związku ze zgłaszanymi przypadkami nieuwzględniania narodowości ankietowanych oraz obawy publicznego deklarowania narodowości związane z dyskryminacją. Przeprowadzona ewidencja ludności pozwala wnioskować, że z jednej strony, mimo wieloletniej państwowej polityki asymilacyjnej mniejszość ukraińska nie tylko przetrwała, ale dzięki zachowanej tożsamości kulturowej, w jakimś stopniu, zrekonstruowała i rozbudowała swoje środowisko, z drugiej zaś konstatować, iż procesy asymilacyjne w dużym stopniu objęły także mniejszość ukraińską.

Przez ponad 65 lat wspólnota obyczajów, tradycjonalizm, rozwój języka oraz poczucie świadomości historycznej kształtowały postawę narodową Ukraińców. Po wysiedleniu społeczność ukraińska podtrzymywała poczucie swojej odrębności i przynależności etnicznej nie tylko w sferze językowej, ale przede wszystkim, poprzez silne przywiązanie do swojej religii, kalendarza liturgicznego i obrzędowości. W takich warunkach, według J. Chlebowczyka, „z przejmowanych z pokolenia na pokolenie wzorów obyczajowych wypływało poczucie bliskości i swojskości, które cementowało w wypadkach konfrontacji z elementem obcym wewnętrzną zwartość danej społeczności" [Chlebowczyk 1983, 41]. Dla społeczności ukraińskiej w Polsce święta religijne są czynnikiem scalającym i integrującym warstwy pokoleniowe, sprzyjają poznawaniu poprzez wierzenia i rytuały religijne wartości kulturowych. Obecnie trwanie tych zwyczajów warunkuje w dużej mierze także to, w jakim stopniu zachowana zostanie rodzima mowa i odrębność etniczno-kulturowa młodej generacji Ukraińców. Z przeprowadzonych rozmów z respondentami wynika, że młodzi Ukraińcy szanują i cenią wspólne podtrzymywanie tradycji świątecznych, które są podstawowym czynnikiem integrującym pokolenia. Przytaczamy wypowiedź młodego respondenta o wspólnym uczestniczeniu rodziny $\mathrm{w}$ rytuałach wigilii Bożego Narodzenia: jak już wszystko było przygotowane do wigilii, to zawsze było tak, że ja, mój brat $i$ tato wchodziliśmy z wiazkami siana do domu, sktadaliśmy życzenia mamie, za które nam dziękowała; nastepnie stawiało się na stole krzyż, wszyscy modliliśmy się, siadaliśmy do stotu, dzieliliśmy sie prosfora $i$ zaczynaliśmy wieczerze [...] a jak zjedliśmy to przed pójściem do cerkwi zaczynaliśmy kolędować, rozpoczynajac od najstarszej kolędy, od Boh predwicznyj narodywsia, a następnie śpiewaliśmy te, które przyszły do głowy. 
Z przeprowadzonych wywiadów na temat tradycji świątecznych kultywowanych w rodzinach informatorów wnioskujemy, że przedstawiciele młodszej generacji w bardzo ogólnym zakresie potrafią scharakteryzować obyczaje świąteczne (przede wszystkim bożonarodzeniowe i wielkanocne), nie znają symboliki obrzędów, pojawiają się trudności z nazwaniem tradycyjnych potraw, z operowaniem leksyką ukraińską. Natomiast starsi respondenci podkreślają, iż w wyniku zacierania się odrębności czy wymieszania tradycji oraz powszechnej globalizacji święta cyklu rocznego zatracają pewne elementy starej obrzędowości i podlegają częściowej uniwersalizacji.

Przeprowadzone rozmowy potwierdzają, że ponad pół wieku integracji społecznej doprowadziło do zróżnicowania samoidentyfikacji młodej generacji, a część członków młodego pokolenia przyjęła język, obyczaje i religię polskiej grupy dominującej zlewając się z większością kulturową. W latach 70 . proces osłabienia spoistości wewnątrzgrupowej determinował przede wszystkim awans społeczny Ukraińców oraz zwiększona migracja do miast, która sprzyjała przyśpieszeniu procesów asymilacyjnych, co nie zawsze było jednoznaczne z całkowitym zerwaniem z kulturą pierwotnej identyfikacji. Jak podkreśla A. Kłoskowska, „identyfikacja narodowa może ulec całkowitej przemianie w toku życia jednostki. Taka przemiana jest tutaj określana jako konwersja narodowa. Może ona mieć różnorodne motywacje i różny stopień internalizacji wynikłego stąd przeobrażenia wartości” [Kłoskowska 2005, 141]. Znamienne dla wielu przedstawicieli mniejszości ukraińskiej jest akceptowanie bikulturowości środowiska i przemian polegającym na „dodaniu” do macierzystej identyfikacji elementów nowej, wiążącej jednostkę z obcą wcześniej grupą tożsamości. Uwzględniając wewnętrzne zróżnicowanie młodzieży, można w tej społeczności wyodrębnić 3 grupy [Горків 2010, online]:

1. Osoby wierne „małej ojczyźnie” swoich przodków, które kultywują przywiązanie do tzw. Zakerzońskiego kraju - ukraiński raj; odwiedzają ziemie przodków, dbają o miejsca pamięci narodowej i cmentarze;

2. Osoby, które małą ojczyznę postrzegają w miejscu urodzenia lub terenach, na które przybyli w celu zdobycia nauki i pracy; w tej grupie widoczne jest rozerwanie związków z terenami południowo-wschodniej Polski;

3. Osoby niezdeklarowane co do własnej przynależności.

Analizy środowiska ukraińskiego potwierdzaja poczucie silnej identyfikacji z narodem ukraińskim przedstawicieli dwóch pierwszych grup. Potwierdzają oni znajomość historii swojego rodu, kultywują tradycje rodzinno-świąteczne (posiadają większą wiedzę w zakresie świąt rocznych niż uroczystości rodzinnych), a naukę języka ukraińskiego uważają za swój obowiązek. Jednak w dobie nowych realiów historyczno-kulturowych, człon- 
kowie młodego pokolenia, podkreślają silną więź identyfikacyjną z regionem zamieszkania oraz jego mieszkańcami. Młodzież wykazuje tendencje stałego zakorzeniania się na Warmii i Mazurach poprzez tworzenie własnej infrastruktury kulturalnej, edukacyjnej i religijnej. Zróżnicowanie wewnętrzne środowiska młodzieżowego pogłębia fakt, że w świadomości wielu młodych Ukraińców upowszechnia się przekonanie o możliwości zachowania tożsamości narodowej bez potrzeby identyfikacji językowej z grupą. Język jest jednym z najistotniejszych wyznaczników kulturowych tożsamości, ale jak zauważa J. Tambor, badaczka mniejszości śląskiej, ,język nie określa identyfikacji narodowej czy etnicznej człowieka jednoznacznie" [Tambor, online].

Powyższe stwierdzenie charakterystyczne jest dla przedstawicieli generacji średniej i młodszej Ukraińców, którzy dostarczają licznych przykładów zaburzenia relacji między językiem i tożsamością, gdzie język staje się dla nich wtórnym czynnikiem tożsamości. Uwzględniając poziom i zakres znajomości ukraińskiego języka literackiego w jego wariancie mieszanym z elementami gwarowymi i obcojęzycznymi, w społeczności młodzieżowej, zróżnicowanie kształtuje się następująco:

1. Młodzież, która ukończyła szkołę z ukraińskim językiem nauczania wyróżnia się dobrym stopniem opanowania kompetencji językowych w języku ojczystym. Przedstawiciele tej grupy raczej bez trudu posługują się ukraińskim językiem literackim z domieszką zapożyczeń i kalek językowych; charakteryzuje ich dobra znajomość historii Ukrainy oraz literatury ukraińskiej, jak również mają rozeznanie w aktualnej sytuacji na Ukrainie.

2. Młodzież, która „wyniosła język z domu” w różnych wariantach gwarowych oraz uczęszczała na naukę języka ukraińskiego do międzyszkolnych zespołów nauczania tego języka. Jest to grupa bardzo zróżnicowana pod względem poziomu i stopnia opanowania języka ukraińskiego. Znamienne jest dla nich stosowanie w wypowiedziach dużej ilości kalek i zapożyczeń, co w rezultacie prowadzi do powstawania indywidualnych idiolektów, interjęzyków.

3. Młodzież polskojęzyczna, która rozpoczyna naukę języka ojczystego w międzyszkolnych zespołach na zasadach języka obcego. Tutaj, u większości, kompetencje językowe ograniczają się do podstawowych sytuacji konwersacyjnych. W języku ukraińskim rozmawiaja jedynie w „ukraińskich miejscach publicznych", poza tymi miejscami konwersacja prowadzona jest $\mathrm{w}$ języku polskim. W tej grupie to rodzice wymuszają postawę bilingwalną dzieci i wyrażają chęć, by dziecko uczyło się języka przodków. 
4. Młodzież, która nie uczyła się ukraińskiego języka literackiego, ale biernie przyswoiła gwarę dziadków.

Na pytanie o „pierwszy przyswojony” język większość młodzieży gimnazjalnej i licealnej wskazała język polski, część „,język z domu”. Nauczyciele języka ukraińskiego potwierdzają, że coraz większy odsetek młodzieży szkolnej wykazuje tendencje monolingwalne, w zatrważającym tempie zmniejsza się liczba dzieci posługującej się językiem ukraińskim w jego odmianie gwarowej lub literackiej. Obecnie dla większości dzieci rozpoczynających naukę języka ukraińskiego jest to język obcy i właśnie takie metody nauczania należy przyjmować, dostosowując programy i zakresy materiałów z języka ukraińskiego do rzeczywistych umiejętności językowych uczących się. Można przypuszczać, iż w ciągu najbliższego ćwierćwiecza społeczność ukraińska będzie w większości polskojęzyczna z poczuciem przynależności do narodu ukraińskiego.

Młodzież wyraźnie różnicuje sytuacje komunikacyjne, dominuje język polski jako podstawowy środek komunikacji, natomiast język ukraiński należy do sfery kontaktów nieoficjalnych - rodzinno-towarzyskich. W celu szybkiego zintegrowania się z otoczeniem dzieci wyzbywają się języka ojczystego na rzecz języka obcego, w tym przypadku, polskiego. Językiem ukraińskim posługują się raczej sporadycznie w kontaktach ze swoją wspólnotą, w nielicznych sytuacjach podczas oficjalnych rozmów z przedstawicielami cerkwi greckokatolickiej oraz ukraińskich struktur organizacyjnych. W tej grupie wiekowej część deklaruje bierną znajomość języka ukraińskiego, który pełni rolę jedynie sakralną, używany jest w obrzędach religijnych oraz nabożeństwach, zatracając swoją funkcję kulturowo-społeczną. Na tę kwestię zwrócił uwagę D. Wojakowski, podkreślając, „[...] w cerkwi język postrzegany jako własność religijna jest przynależny do liturgii i religii, a zatem występuje $\mathrm{w}$ innej roli: $\mathrm{w}$ tym przypadku można go raczej traktować jako element religii, systemu kulturowego" [Wojakowski 2002, 148, 149]. Cerkiew postrzegana jest przez młodych Ukraińców jako ostoja języka ukraińskiego i bastion ukraińskości, a zachowanie w przeszłości przynależności do obrządku wschodniego, zdaniem wielu, umacniało poczucie przynależności religijno-narodowościowej. Cerkiew greckokatolicka do 1952 roku miała formalny zakaz prowadzenia działalności, a wszystkie formalne próby ze strony księży greckokatolickich czy wiernych tego obrządku umożliwiające organizację nabożeństw greckokatolickich były przez ówczesne władze skutecznie blokowane, ponieważ celem była likwidacja Cerkwi greckokatolickiej. Wiele rodzin stanęło przed trudnym wyborem przejścia na katolicyzm lub przyłączenia do wyznania prawosławnego. A. Korzeniewska wskazuje, że po przesiedleniu władza komunistyczna wspiera- 
ła działalność cerkwi prawosławnej, ,jeszcze w 1971 roku w założeniach polityki wyznaniowej na ten rok zalecano: udzielać poparcia i stosować możliwe ułatwienia Cerkwi prawosławnej, przede wszystkim w staraniach zmierzających do umacniania i rozszerzania wpływów wśród grekokatolików, w efekcie ograniczających oddziaływanie władz Kościoła rzymskokatolickiego na ludność ukraińską" [Korzeniewska 2006, 74]. Po długim okresie marginalizacji wyznaniowej grekokatolików, dopiero po zmianach ustrojowych 1989 r., działalność cerkwi greckokatolickiej uaktywniła się poprzez mianowanie bpa Jana Martyniaka ordynariuszem greckokatolickiej diecezji przemyskiej, nastąpiła rozbudowa jej sieci organizacyjnej i uzyskanie osobowości prawnej. Wizualnymi przykładami legalizacji Cerkwi greckokatolickiej w Polsce się elementy architektury cerkiewnej w postaci charakterystycznych bań, które na stałe wpisały się w krajobraz architektoniczny Warmii i Mazur.

Analiza rozmów z respondentami potwierdza nieznajomość gwary swoich przodków u większości młodych Ukraińców, którzy na płaszczyźnie komunikacji wykorzystują czasami ukraiński język literacki z dużą domieszką kalek językowych z języka polskiego oraz struktur hybrydalnych. Przeprowadzone eksploracje pokazują, że obecnie, w porównaniu z latami 80-90, gdy młodzież dążyła do nabywania podwójnej kompetencji językowej, w nielicznych domach ukraińskich rozbrzmiewa język rodzimy. Gdzie leżą przyczyny tego, że w rodzinie, w której oboje rodzice są Ukraińcami, dobrze znającymi język ukraiński, w sferze komunikacji z dziećmi wykorzystują język polski? Jakie czynniki zadecydowały o tym, że język ukraiński nie jest pielęgnowany $\mathrm{w}$ domu $\mathrm{i}$ w rodzinie? Zaistniałą sytuację tłumaczy się czynnikami zewnętrznymi (sąsiedztwo, szkoła, rówieśnicy) oraz obawami przed kategoryzacją i stereotypizacją. To przede wszystkim chęć rodziców do bezproblemowego identyfikowania się dziecka z grupą rówieśniczą powoduje odrzucenie lub ukrywanie języka rodzimego. Wśród młodzieży panuje przekonanie, że język nie jest niezbędnym czynnikiem konsolidacyjnym i wykładnikiem świadomości narodowej. Nie jawi się on także jako język kariery. Nawet na różnorodnych ukraińskich festiwalach folklorystycznych i akademiach rocznicowych trudno nie zauważyć, iż zjawisko bilingwizmu językowego charakterystyczne dla respondentów średniego pokolenia zostaje zdominowane przez proces asymilacji językowej u 30 i 20-latków oraz młodszych przedstawicieli. W warunkach galopujących procesów asymilacyjnych szkoła ukraińska stawia sobie priorytetowe zadanie zachowania i kultywowania tożsamości językowej młodzieży ukraińskiej. Skuteczna realizacja założonego celu uzależniona jest od zaangażowania nauczycieli, przedstawicieli ukraińskich struktur organizacyjnych, a przede wszystkim rodziców. Szkoła, 
jak podkreśla Wojakowski, to jedyny czynnik, który może wpłynąć na to, że nie zniknie obecny wątły pluralizm językowy [Wojakowski 2002, 146]. M. Syrnyk - przewodniczący Związku Nauczycielstwa Ukraińskiego w Polsce, dodaje z przekonaniem, że „szkoły ukraińskie to miejsce, które zwiększa szansę na to, że młodzież ukraińska nie rozpuści się w polskim morzu" [Гopків 2010, online].

Na Warmii i Mazurach funkcjonują dwie szkoły z ukraińskim językiem wykładowym: w Bartoszycach i Górowie Iławeckim. W szkole bartoszyckiej kształcenie prowadzone jest na I, II i III poziomie edukacyjnym, tj. podstawówka i gimnazjum, natomiast w Górowie zajęcia prowadzone są dla uczniów gimnazjum i liceum. W Bartoszycach w roku szkolnym 20013/14 naukę w zerówce rozpoczęło 12 dzieci i 10 osób w I klasie szkoły podstawowej; w roku 2014/15 naukę rozpoczęło odpowiednio 16 uczniów w zerówce, $13 \mathrm{w}$ pierwszej klasie szkoły podstawowej i $12 \mathrm{w}$ gimnazjum. W Zespole Szkół z Ukraińskim Językiem Nauczania w Bartoszycach łączna liczba uczniów w roku 2014/15 wynosi 132 osoby. Liczba uczniów przybyłych w roku szkolnym 2013/14 do pierwszych klas to odpowiednio 40 osób $\mathrm{w}$ liceum (w tym troje dzieci z Kaliningradu) oraz 14 osób w gimnazjum (3 z Kaliningradu). [Лоза 2013, 1]. Natomiast rok szkolny 2014/15 w liczbach przedstawia się następująco: 20 uczniów w I klasie gimnazjum (tym 3 uczniów z Ukrainy) oraz 43 osoby w I klasie liceum (w tym 22 osoby z Ukrainy). W tej szkole naukę pobiera 161 osób. Oprócz wymienionych szkół na Warmii i Mazurach funkcjonuje ponad 40 tzw. Międzyszkolnych Zespołów Nauczania Języka Ukraińskiego, tworzonych przez dyrektorów szkół na wniosek rodziców. W takich punktach nauką objętych jest ponad $70 \%$ procent dzieci z rodzin ukraińskich. Lekcje prowadzone są w wymiarze 3 godzin tygodniowo i przeważnie odbywają się w późnych godzinach popołudniowych. Od wielu lat w Warmińsko-Mazurskim Ośrodku Doskonalenia Nauczycieli, na część etatu, zatrudniany jest doradca metodyczny w zakresie nauczania języka ukraińskiego. Od 2003 r. funkcję tę pełni pani Lubomira Tchórz - dyrektor Zespołu Szkół z Ukraińskim Językiem nauczania w Bartoszycach. Warmińsko-Mazurski Ośrodek Doskonalenia Nauczycieli w Elblągu zatrudnia także konsultanta do spraw religii grecko-katolickiej.

Wywiady z respondentami wykazały, że pokolenie młodzieży ukraińskiej dostrzega różnice między własnym językiem, a językiem, którym posługują się ich rodzice i dziadkowie. Większość młodych rozmówców z trudem wypowiadało się w języku ukraińskim i mimo deklaracji odnośnie kultywowania tradycji przodków nie dysponowało wystarczającym zasobem leksykalnym, by konstruować zwarte i poprawne wypowiedzi w języku ukra- 
ińskim o nazewnictwie obrzędowym. Wpływ języka polskiego jest tutaj zdecydowanie bardziej widoczny i słyszalny. Potomkowie przesiedleńców, jeżeli nawet $\mathrm{w}$ dzieciństwie opanowali mowę swoich przodków, to w dalszej perspektywie związanej z nauką i pracą w środowisku polskojęzycznym, nie zdołali przyswoić sobie niezbędnego zapasu słownictwa gwarowego lub języka literackiego, co wpłynęło na wysoki stopień hybrydyzacji języka młodzieży.

Mniejszość ukraińska na Warmii i Mazurach zrzeszona jest w Związku Ukraińców w Polsce. W 1994 r. zainaugurował działalność Oddział Związku Niezależnej Młodzieży Ukraińskiej w Olsztynie. Samorząd Województwa współpracuje z instytucjami mniejszościowymi, a w 1994 r. został powołany pełnomocnik ds. mniejszości narodowych i etnicznych (od 6 lat funkcję pełnomocnika sprawuje pani J. Sobiesiak-Wańkowska).

W 1999 r. Sejmik Województwa Warmińsko-Mazurskiego powołał Komisję ds. Mniejszości Narodowych i Etnicznych, do której weszli przedstawiciele wszystkich mniejszości. Samorząd rezerwuje środki na wspieranie projektów kulturalnych mniejszości, wspierając finansowo i organizacyjnie ich działalność. Współpraca na szczeblu międzyregionalnym, miast, gmin oraz powiatów zaowocowała szeregiem dużych imprez kulturalnych w regionie, np. Festiwal Narodów Europy „Pod wspólnym niebem” (Olsztyn, Ostróda), Międzynarodowy Festiwal Telewizyjno-Radiowy „Kalinowe Mosty” (Olsztyn), Barwy Kultury Ukraińskiej (Banie Mazurskie), „E-kołomyja” (Górowo Iławeckie), Pasłęcka Uczta Kultur Wschodu (Pasłęk), Noc Iwana Kupały (Kruklanki), Dni Kultury Ukraińskiej (Giżycko), Regionalny Ukraiński Jarmark „Z malowanej skrzyni” (Kętrzyn), Międzynarodowe Dni Muzyki Cerkiewnej (Giżycko), Dni teatru Ukraińskiego (Olsztyn), Spotkania z Folklorem Ukraińskim (Dobre Miasto), Festyn Ludowy (Asuny), Otwarcie Sezonu Kulturalnego Ukraińców Warmii i Mazur (Srokowo), Międzynarodowy Festiwal Dziecięcych Zespołów Folklorystycznych Mniejszości Narodowych (Węgorzewo), Przegląd Ukraińskiej Poezji Śpiewanej i Twórczości Poetyckiej (Olsztyn), Przegląd Małych Form Teatralnych (Bartoszyce), Przegląd Kolęd i wertepów (Węgorzewo), Dziecięcy Festiwal Kultury Ukraińskiej (Elbląg), Ukraińskie Dożynki (Pieniężno), coroczne Dni Szewczenkowskie w całym regionie.

Dodatkowo w szkołach i międzyszkolnych zespołach prowadzona jest działalność kulturalna, funkcjonują zespoły artystyczne i teatralne, np. Zespół Pieśni i Tańca „Dumka” (Górowo Iławeckie, Szkoła z Ukraińskim Językiem Nauczania), „Lisowa Pisnia” oraz „Dar Lubowi” (Bartoszyce, Szkoła z Ukraińskim Językiem Nauczania), Dziecięcy Zespół Wokalny „Suzirjaczko" (Olsztyn, Międzyszkolny Zespół Nauczania Języka Ukraińskiego), 
Zespół Tańca „Czeremosz” (Węgorzewo), działający pod patronatem Stowarzyszenia Czeremosz i Domu Kultury, „Lelkiwśki Wesełuszky” (Lelkowo, Międzyszkolny Zespół NJU).

W środowisku polskim tożsamość kulturowa mniejszości ukraińskiej zaznała długotrwałego wzajemnego oddziaływania. Kontakt kulturowy doprowadził do dobrowolnej akulturacji części społeczności ukraińskiej aprobującej zewnątrzkulturowy przekaz oraz do sytuacji, gdy do dziedzictwa kulturowego Ukraińców zapożyczone zostają elementy kultury polskiej. Poczucie zagrożenia procesami asymilacyjnymi wpłynęło na konsolidację Ukraińców, skłoniło ich do określenia swojej odmienności i zagłębienie się w swojej kulturze. Jak podkreśla M. Golka, „konstruowanie tożsamości polega na tym, by dopasować się do zróżnicowanego świata, ale polega też na tym, by dopasować ten zróżnicowany świat do siebie" [Golka 2012,]. Współcześnie Ukraińcy Warmii i Mazur wpisują się aktywnie w tworzenie wielokulturowości tego regionu, podkreślają swoją obecność poprzez promowanie działalności kulturowej.

\section{Literatura}

Barwiński M., 2014, Struktura narodowościowa Polski w świetle wyników spisu powszechnego z 2011 roku, „Przegląd Geogeaficzny”, 86, 2, s. 217-241.

Barwiński M., 2013, Geograficzno-polityczne uwarunkowania sytuacji Ukraińców Łemków, Białorusinów i Litwinów w Polsce po 1944 roku, Łódź.

Beba B., Pijanowska J., 1998, Demograficzne uwarunkowania rozwoju kultury na Warmii i Mazurach, [w:] B. Domagała i A. Sakson (red.), Tożsamość kulturowa spoleczeństwa Warmii i Mazur, Olsztyn, s. 23-33.

Beba B., 1998, Kierunek przemian tożsamości kulturowej Ukraińców na Warmii i Mazurach, [w:] B. Domagała i A. Sakson (red.), Tożsamość kulturowa spoteczeństwa Warmii i Mazur, Olsztyn, s. 96-108.

Chlebowczyk J., 1983, O prawie bytu matych i młodych narodów, Warszawa - Kraków, s. 41.

Chmielewski D., 2013, Nowa przestrzeń budowania tożsamości. Lokalne instytucje kultury w społeczeństwie postmigracyjnym, [w:] L. Dyczewski, K. Jurek, (red.), Tożsamość w wielokulturowym kontekście, Lublin-Warszawa, s. $351-371$.

Domagała B., 2005, Polityka multikulturalizmu i problemy mniejszości na Warmii i Mazurach, [w:] Forum politologiczne, t. 2 UWM, Olsztyn, s. 87.

Drozd R. (red.), 2007, Ukraincy w najnowszych dziejach Polski 1918-1989, t. III, Słupsk. 
Golka M., 2012, Doświadczanie tożsamości w warunkach wielokulturowości, „Przegląd Zachodni”, Poznań, nr 1.

Hrywna I., 1998, Życie społeczno-kulturalne Ukraińców na Warmii i Mazurach, [w:] B. Domagała i A. Sakson (red.), Tożsamość kulturowa społeczeństwa Warmii i Mazur, Olsztyn, s. 109-117.

Kłoskowska A., 2005, Kultury narodowe u korzeni, Warszawa, s. 141.

Konieczna J., Polacy-Ukraińcy. Polska-Ukraina. Paradoksy stosunków sasiedzkich, [online], http://www.pauci.org/file/cGF1Y2lfZmlsZXMyNzg2.pdf, [6.09.2014]

Korzeniewska A., 2006, Kościół greckokatolicki na Warmii i Mazurach po II wojnie światowej, [w:] Studia Warmińskie XLIII, Olsztyn, s. 74.

Marciniak T., 1998, Ukraińcy Wschodnich Mazur. Istnienie realne obecność symboliczna, [w:] B. Domagała i A. Sakson (red.), Tożsamość kulturowa społeczeństwa Warmii i Mazur pod, Olsztyn, s. 118-127.

Protokół Nr 20/2009 z posiedzenia Komisji ds. Mniejszości Narodowych i Etnicznych w dniu 20 aździernika 2009 r., Kancelaria Sejmiku Województwa Warmińsko-Mazurskiego, [online], http://www.google.pl/url?sa=t\&rct=j\&q=\&e $\mathrm{src}=\mathrm{s} \&$ source $=$ web\&cd $=1 \&$ ved $=0 \mathrm{CCAQFjAA} \& u r l=\mathrm{http} \% 3 \mathrm{~A} \% 2 \mathrm{~F} \% 2 \mathrm{Fbip}$. warmia.mazury.pl\%2Furzad_marszalkowski\%2Fsystem\%2Fpobierz.php\%3F id\%3D69 [17.06.2014].

Skorowski H., 2013, Tożsamość pluralistyczna. Sprzeczność czy harmonia?, [w:] L. Dyczewski, K. Jurek (red.), Tożsamość w wielokulturowym kontekście, Lublin-Warszawa, s. 9-28.

Tambor J., Kulturowe wyznaczniki tożsamości. Tożsamość mieszkańców województwa ślaskiego, [online], https://www.google.pl/?gfe_rd=cr\&ei=LjdWVLX6A qeF8QfH1oHIDg\#q=Tambor+J.\%2C+Kulturowe+wyznaczniki+to $\%$ C5\% BCsamo $\%$ C5\%9Bci.+To\%C5\%BCsamo\%C5\%9B $\%$ C4\%87+mieszka $\%$ C5\%8 4c\%C3\%B3w+wojew\%C3\%B3dztwa+\%C5\%9Bl\%C4\%85skiego, [20.06.2014].

Tomanek P., 2003, Ochrona praw językowych mniejszości narodowych w Polsce ze szczególnym uwzględnieniem mniejszości ukrainskiej, [w:] B. Zinkiewicz-Tomanek, A. Fałowski (red.), Studia Ruthenica cracoviensia 1. Ukraina. Między językiem a kulturą, Kraków, s. 245-260.

Wojakowski D., 2002, Polacy i Ukraińcy. Rzecz o pluralizmie i tożsamości na pograniczu, Kraków, s. 148-149.

Горків I., 2010, Молоде покоління украӥnciv и Polbщі. Poglsd z seredini, [w:] Рідна мова, № 27, [online], http://www.interklasa.pl/portal/dokumenty/rid na_mowa_uk/index.php?page=rm27_03, [2.08.2014]

Лоза П., 2013, У школох стабільно ... поки що, [w:] Наше слово, № 36, с. 1. 


\section{CULTURAL IDENTITY AND LINGUISTIC IDENTIFICATION OF THE UKRAINIANS IN WARMIA AND MAZURY}

\section{S U M M A R Y}

Relocated to Warmia and Mazury in 1947, the Ukrainians comprised $10 \%$ of the inhabitants of the region. At present, Ukrainians are the most numerous minority group in Warmia and Mazury, living in the northern part of the region. A report of the Institute of Public Affairs has shown that Warmia and Mazury - as a multicultural and multi-ethnic environment - is a region characterised by a higher tolerance towards otherness and an exceptionally friendly approach towards the Ukrainian minority.

This article is an attempt to outline the modern developmental trends with regard to the socio-cultural identity of the Ukrainians who live in the region of Warmia and Mazury. We also mention how their linguistic identification is shaped. Most of the Ukrainians of the older and middle generations equal national identity with using the Ukrainian language in its colloquial dialect or literary variety, while the young Ukrainians associate the language with a purely symbolic status. The youth emphasise that their culture and identity do not have to be expressed through using the Ukrainian language.

After 1991, the Ukrainian minority has become increasingly assertive in using the rights granted them, encouraging local governments to subsidy their cultural programmes and support them on the organisational plane. Cooperation at the level of regions, towns, communes and districts has resulted in a number of important cultural events in the region of Warmia and Mazury. Schools also conduct cultural activity, with bands and theatrical groups actively participating in building the multicultural character of the region.

The present research has shown that the compulsory cultural contact led to voluntary acculturation of some members of the Ukrainian community, and to a situation in which elements of the Polish culture are interwoven into the Ukrainian cultural heritage.

Mirosława Czetyrba-Piszczako e-mail: zbp58@interia.pl

Maria Czetyrba e-mail: m.czetyrba@gmail.com 